www.jmscr.igmpublication.org

Index Copernicus Value: 79.54

ISSN (e)-2347-176x ISSN (p) 2455-0450

crossrefDOI: https://dx.doi.org/10.18535/jmscr/v7i2.130

\title{
Study of Cardiac Abnormalities in HIV Patients and their Correlation with CD4 Count
}

\author{
Authors \\ Dr G. Chinna Mariappan M.D. ${ }^{1}$, Dr T.M. Prabhu M.D. ${ }^{2}$ \\ ${ }^{1}$ Assistant Professor, Department of Medicine, Pudukottai Medical College, Pudukottai \\ ${ }^{2}$ Assistant Professor, Department of Medicine, KAPV Govt Medical College, Trichy
}

\section{Introduction}

Human immunodeficiency virus is a retrovirus that affects all systems in the body. Among this cardiovascular disease is one of the leading causes of non HIV related death in HIV patients. Risk factors for cardiovascular disease in HIV patients include traditional risk factors, chronic inflammation associated with HIV infection and metabolic effects of antiretroviral therapy. HIV infection itself is a independent risk factor for cardiovascular diseases.

HIV infection increases the production of various cytokines which are toxic to myocytes and thereby increases the risk of cardiovascular complications. HIV infection induced endothelial dysfunction and vasculitis is also playing an important role in pathogenesis of these complications.

Although many cardiovascular complications have been described like pulmonary hypertension, systemic hypertension, infective endocarditis and accelerated atherosclerosis in HIV patients, the most common complications include diastolic dysfunction, left ventricular systolic dysfunction ,pericardial effusion, dilated cardiomyopathy and coronary artery disease. Rapid onset congestive heart failure leads to death in HIV patients within 6 to 12 months of diagnosis.

As the disease progresses the CD4 count declines which increases the cardiovascular complications leading to death. So echocardiographic screening should be performed in all HIV patients with low CD4 count for early detection and management of the complications.

This study was conducted to study the prevalence of cardiac complications in HIV patients and their correlation with CD4 count.

\section{Aims and Objectives}

1. To assess the cardiac abnormalities such as systlolic dysfunction, diastolic dysfunction, dilated cardiomyopathy, coronary artery disease, pulmonary hypertension and infective endocarditis and their correlation with CD4 count.

2. To evaluate whether this parameter can be used as prognostic marker of disease progression in HIV patients. 


\section{Materials and Methods}

Participants: 200 HIV positive patients $>12$ years of age coming to ART centre, Govt. Rajaji Hospital, Madurai.

\section{Study Population}

This study was conducted among 200 HIV positive patients coming to ART centre, Govt. Rajaji Hospital, Madurai. CD4 count, ECG and Echocardiograrm were done in all the participants of the study. Cases were classified as HIV patients into four groups depending upon the CD4 cell count >500 stage1), CD4 cell count $200-500$ (stage 2), and 50-200(stage 3) and <50 stage 4.

\section{Inclusion Criteria}

- Age $>12$ yrs

- Newly diagnosed HIV patients

- Patients on ART therapy

\section{Exclusion criteria}

\section{Patients with}

* Valvular heart disease.

* Coronary artery disease.

* Congenital heart disease

* Rheumatic heart disease

* Thyroid disorders

* Pregnant women

\section{Data Collection}

A detailed history with detailed clinical examination was done for the HIV positive individuals. The blood samples of people belonging to study groups were tested for CD4 cell count. ECG and echocardiogram were done in study group.

\section{Laboratory Investigations}

Blood samples were collected from the study group and CD4 counts were obtained by flow cytometry. Here the cells were conjugated to monoclonal antibodies against CD3 and CD4 cell surface markers. These cells were then made to pass through a flow chamber and subjected to intersection by a LASER beam. The flourescent signals obtained from the LASER beam intersecting the cells were analysed and data obtained helped delineate the different cell sub populations based on their cluster differentiation. 12 lead ECG and Echocardiogram were done in study group.

\section{Data Analysis}

The final data was entered onto Microsoft excel sheet 2007 version and statistical analysis was done using SPSS software and chi - square test. The results were considered very significant with $\mathrm{p}$ value $<0.01$ and significant with $\mathrm{p}$ value $<0.05$.

\section{Study Protocol}

$>$ All cases were classified into 3 categories based on CD4 cell count

$>12$ lead ECG and Echocardiogram were done in study group.

Design of study: Prospective analytical study

Period of study: 5 months (APRIL 2014 TO AUGUST2014)

Collaborating departments:

$\checkmark$ Department of Medicine,

$\checkmark$ Department of Cardiology

$\checkmark$ Regional ART centre

Ethical clearance: Obtained

Consent: Individual written and informed consent.

Analysis: Statistical analysis-chi square test

Conflict of interest: NIL

Financial support: NIL

\section{Observation and Results}

Table 1 Age distribution of the study population $(\mathrm{n}=200)$

\begin{tabular}{|l|c|c|}
\hline AGE GROUP & FREQUENCY & PERCENTAGE \\
\hline $12-20$ & 6 & $3 \%$ \\
\hline $21-30$ & 48 & $24 \%$ \\
\hline $31-40$ & 60 & $30 \%$ \\
\hline $41-50$ & 56 & $28 \%$ \\
\hline $51-60$ & 28 & $14 \%$ \\
\hline $61-70$ & 2 & $1 \%$ \\
\hline TOTAL & 200 & $100 \%$ \\
\hline
\end{tabular}

Comments: About $54 \%$ of study population were in the age group of 21-40 years and $42 \%$ of study populalation were in the age group of 41-60 years 
Chart 1: Age distribution in the study population

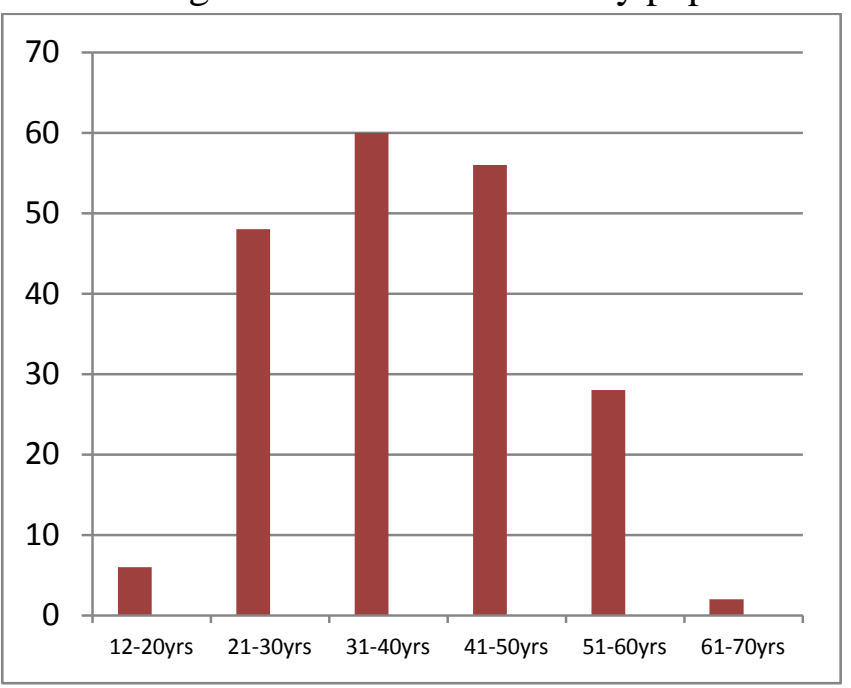

Comment: Most of study population were in the age group of 21 to 50years

Table 2 Gender distribution in the study population $(\mathrm{n}=200)$

\begin{tabular}{|l|c|c|}
\hline GENDER & FREQUENCY & PERCENTAGE \\
\hline MALE & 109 & $54.5 \%$ \\
\hline FEMALE & 91 & $45.5 \%$ \\
\hline TOTAL & 200 & $100 \%$ \\
\hline
\end{tabular}

Comments: Males and females were almost equal in the study population

Table 3 Distribution of the study population according to ART status $(\mathrm{n}=200)$

\begin{tabular}{|l|c|c|}
\hline ART STATUS & FREQUENCY & PERCENT \\
\hline ON ART & 160 & $80 \%$ \\
\hline NEWLY DIAGNOSED & 40 & $20 \%$ \\
\hline TOTAL & 200 & $100 \%$ \\
\hline
\end{tabular}

Comment: Most of the study population were on ART.

Table 4 Staging of CD4 count in the study population $(\mathrm{n}=200)$

\begin{tabular}{|l|c|c|}
\hline CD4 C0UNT & FREQUENCY & PERCENT \\
\hline STAGE $1:>500$ & 60 & $30 \%$ \\
\hline STAGE 2: $200-500$ & 54 & $27 \%$ \\
\hline STAGE $3: 50-200$ & 46 & $23 \%$ \\
\hline STAGE $4:<50$ & 40 & $20 \%$ \\
\hline TOTAL & 200 & $100 \%$ \\
\hline
\end{tabular}

Comments: About $57 \%$ of population in the study group were stage $1 \& 2$ and about $43 \%$ of population in the study group were stage $3 \& 4$.
Chart 2: CD4 count staging in the study population

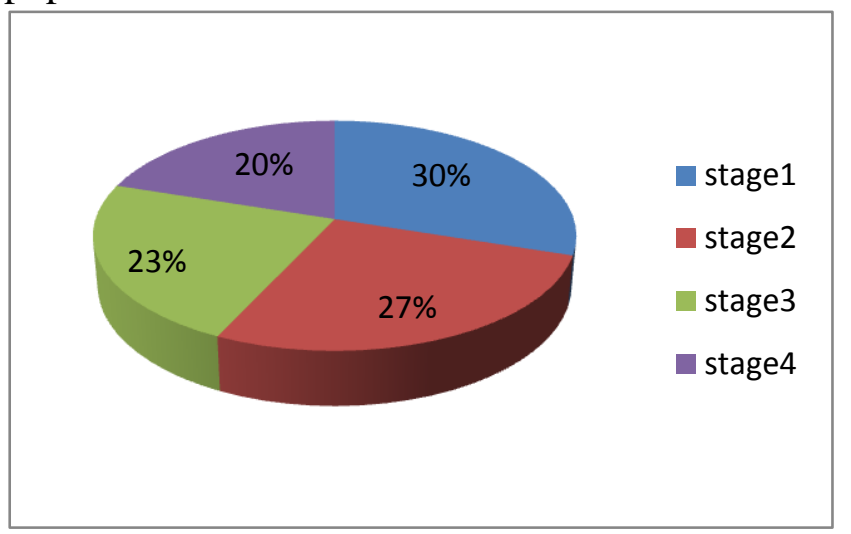

Comments: About $57 \%$ of the study population were in stage $1 \& 2$ and $43 \%$ of study population in stage $3 \& 4$.

Table 5 Prevalence of ECG abnormalities in the study population $(n=200)$

\begin{tabular}{|l|c|c|}
\hline $\begin{array}{l}\text { ECG } \\
\text { ABNORMALITIES }\end{array}$ & FREQUENCY & PERCENTAGE \\
\hline PRESENT & 58 & $29 \%$ \\
\hline ABSENT & 142 & $71 \%$ \\
\hline TOTAL & 200 & 100 \\
\hline
\end{tabular}

ECG abnormalities in the study population

\begin{tabular}{|l|c|c|}
\hline $\begin{array}{l}\text { ECG } \\
\text { ABNORMALITIES }\end{array}$ & FREQUENCY & PERCENTAGE \\
\hline $\begin{array}{l}\text { Poor progression of } \\
\text { R wave }\end{array}$ & 26 & $13 \%$ \\
\hline Low voltage QRS & 18 & $9 \%$ \\
\hline RBBB & 10 & $5 \%$ \\
\hline LBBB & 4 & $2 \%$ \\
\hline TOTAL & 58 & $29 \%$ \\
\hline
\end{tabular}

Comments: ECG abnormalities were present in $29 \%$ of the study population ant most common finding was poor progression of $\mathrm{R}$ wave.

Chart 3: Prevalence of ECG abnormalities in study population $(n=200)$

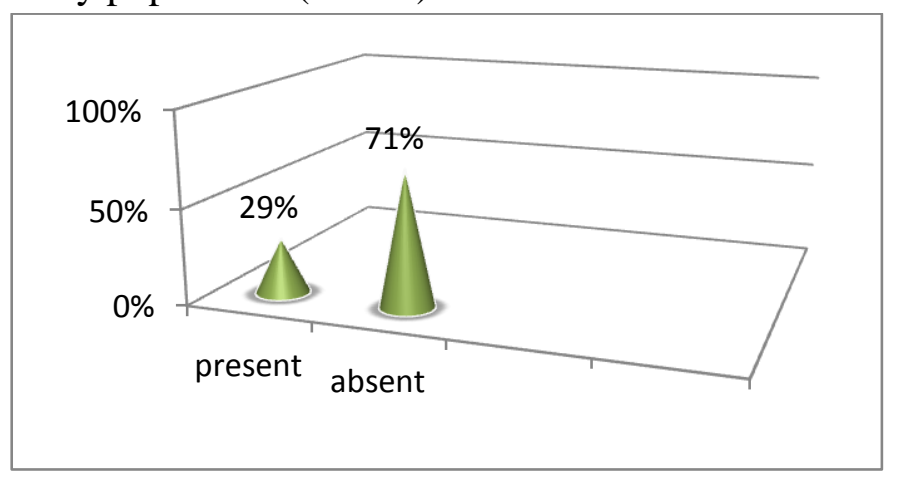

Comments: ECG abnormalities were present in about $29 \%$ of study population . 
Table 6 Prevalence of pericardial effusion in the study population $(\mathrm{n}=200)$

\begin{tabular}{|l|c|c|}
\hline $\begin{array}{l}\text { PERICARDIAL } \\
\text { EFFUSION }\end{array}$ & FREQUENCY & PERCENTAGE \\
\hline PRESENT & 30 & $15 \%$ \\
\hline ABSENT & 170 & $85 \%$ \\
\hline TOTAL & 200 & $100 \%$ \\
\hline
\end{tabular}

Comments: Pericardial effusion was present in around $15 \%$ of study population.P value is $<0.001$ signnificant .

Chart 4: CD4 count staging and pericardial effusion in the study group

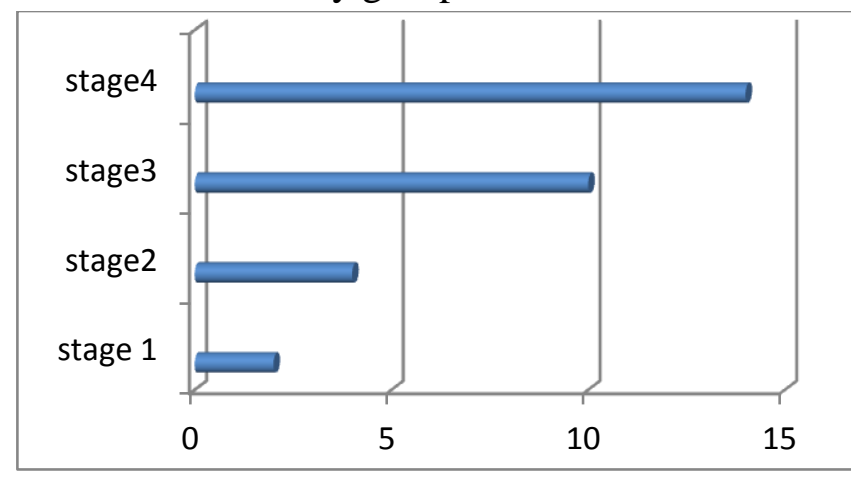

$P$ value $;<0.012$ significant

Comments: The difference in proportions of pericardial effusion in stage $1 \& 2$ and stage $3 \& 4$ is statistically significant and prevalence of pericardial effusion showed a close association with decreasing CD4 count.

Table 7 Prevalence of systolic dysfunction in the study group $(\mathrm{n}=200)$

\begin{tabular}{|l|c|c|}
\hline $\begin{array}{l}\text { SYSTOLIC } \\
\text { DYSFUNCTION }\end{array}$ & FREQUENCY & PERCENTAGE \\
\hline PRESENT & 26 & $13 \%$ \\
\hline ABSENT & 174 & $87 \%$ \\
\hline TOTAL & 200 & $100 \%$ \\
\hline
\end{tabular}

Comment: Systolic dysfunction was present in around $13 \%$ of study population.P value is $<0.001$ significant.
Chart 5: CD4 count staging and systolic dysfunction in the study group $(n=200)$

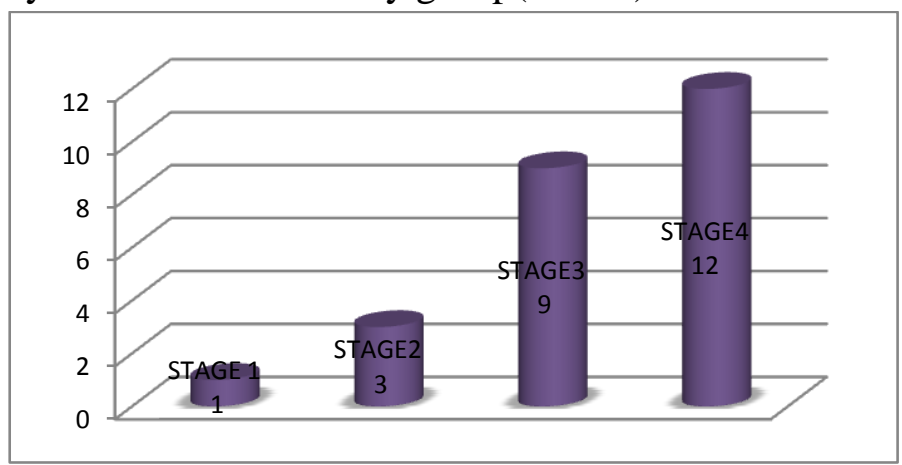

$P$ value $<0.018$ significant.

Comments: The difference in proportions of systolic dysfunction in stage $1 \& 2$ and stage $3 \& 4$ is statistically significant and prevalence of systolic dysfunction showed a close association with decreasing CD4 count.

Table 8 Prevalence of diastolic dysfunction in the study population $(\mathrm{n}=200)$

\begin{tabular}{|l|l|l|}
\hline $\begin{array}{l}\text { DIASTOLIC } \\
\text { DYSFUNCTION }\end{array}$ & FREQUENCY & PERCENTAGE \\
\hline PRESENT & 23 & $11.5 \%$ \\
\hline ABSENT & 187 & $88.5 \%$ \\
\hline TOTAL & 200 & $100 \%$ \\
\hline
\end{tabular}

Comment: Diastolic dysfunction was present in around $11.5 \%$ of study population.P value is $<0.001$ significant

Chart 6: CD4 count staging and diastolic dysfunction in the study group $(n=200)$

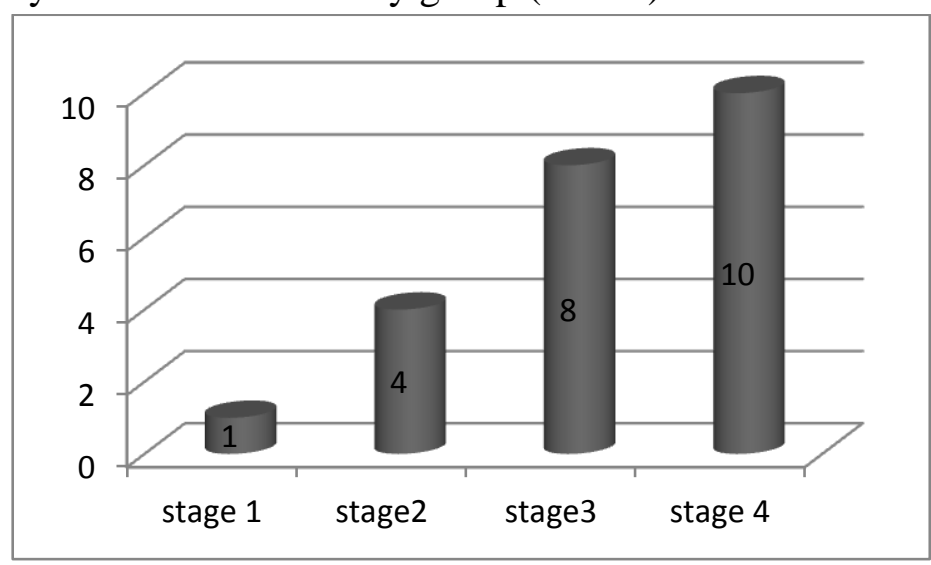

$P$ value $<0.046$ significant

Comments: The difference in proportions of diastolic dysfunction in stage $1 \& 2$ and stage $3 \& 4$ is statistically significant and prevalence of diastolic dysfunction showed a close association with decreasing CD4 count 
Table 9 Prevalence of dilated cardiomyopathy in the study population $(n=200)$

\begin{tabular}{|l|c|c|}
\hline DCM & FREQUENCY & PERCENTAGE \\
\hline PRESENT & 18 & $9 \%$ \\
\hline ABSENT & 182 & $91 \%$ \\
\hline TOTAL & 200 & $100 \%$ \\
\hline
\end{tabular}

Comment: Dilated cardiomyopathy was present in around $9 \%$ of study population. $\mathrm{P}$ value is $<0.001$ significant

Chart 7: Prevalence of dilated cardiomyopathy in the study population

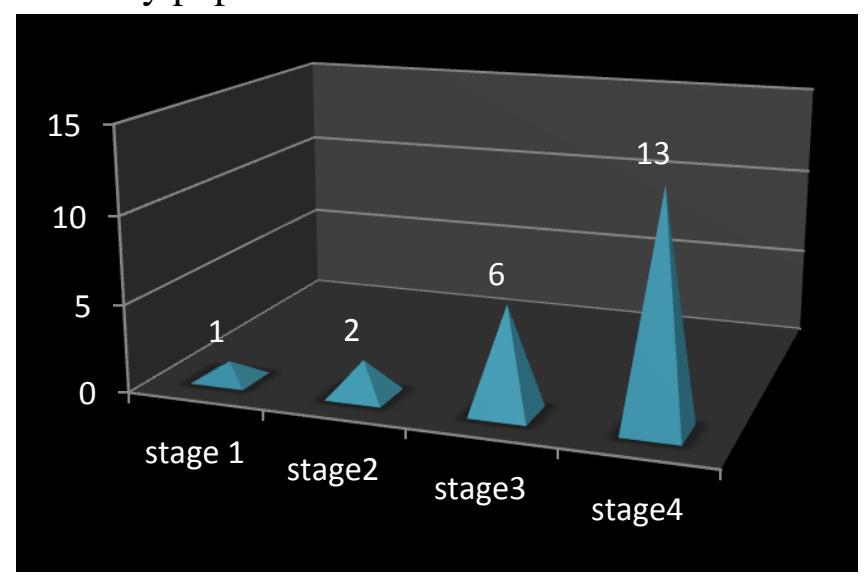

$P$ value $<0.023$ significant

Comments: The difference in proportions of dilated cardiomyopathy in stage $1 \& 2$ and stage $3 \& 4$ is statistically significant and prevalence of dilated cardiomyopathy showed a close association with decreasing CD4 count

Table 10 Prevalence of other abnormalities in the study population $(\mathrm{n}=200)$

\begin{tabular}{|l|c|c|}
\hline $\begin{array}{l}\text { OTHER } \\
\text { ABNORMALITIES }\end{array}$ & FREQUENCY & PERCENTAGE \\
\hline RWMA & 3 & $1.5 \%$ \\
\hline $\begin{array}{l}\text { INFECTIVE } \\
\text { ENDOCARDITIS }\end{array}$ & 1 & $0.5 \%$ \\
\hline $\begin{array}{l}\text { PULMONARY } \\
\text { HYPERTENSION }\end{array}$ & 4 & $2 \%$ \\
\hline TOTAL & 8 & $4 \%$ \\
\hline
\end{tabular}

Comments: Prevalence of other cardiac abnormalities were present in $4 \%$ of the study population
Table 11 Correlation of various cardiac abnormalities and CD4 count

\begin{tabular}{|l|c|c|c|c|c|c|}
\hline $\begin{array}{l}\text { Cardiac } \\
\text { abnormalities }\end{array}$ & stage1 & $\begin{array}{c}\text { stage } \\
2\end{array}$ & $\begin{array}{c}\text { stage } \\
3\end{array}$ & Stage4 & Total & $\begin{array}{c}\text { P } \\
\text { value }\end{array}$ \\
\hline $\begin{array}{l}\text { Pericardial } \\
\text { effusion }\end{array}$ & 2 & 4 & 10 & 14 & 30 & 0.012 \\
\hline $\begin{array}{l}\text { Systolic } \\
\text { dysfunction }\end{array}$ & 2 & 3 & 9 & 12 & 26 & 0.018 \\
\hline $\begin{array}{l}\text { Diastolic } \\
\text { dysfunction }\end{array}$ & 1 & 4 & 8 & 10 & 23 & 0.046 \\
\hline $\begin{array}{l}\text { Dilated } \\
\text { cardiomyopathy }\end{array}$ & 1 & 3 & 6 & 8 & 18 & 0.023 \\
\hline RWMA & 0 & 1 & 1 & 1 & 3 & 0.453 \\
\hline $\begin{array}{l}\text { Infective } \\
\text { endocarditis }\end{array}$ & 1 & 2 & 1 & 0 & 4 & 0.836 \\
\hline $\begin{array}{l}\text { Pulmonary } \\
\text { hypertension }\end{array}$ & 0 & 1 & 0 & 1 & 0.665 \\
\hline
\end{tabular}

\section{Comments}

$>$ All the cardiac abnormalities were prevalent in stage $3 \& 4$ and the $p$ value is significant

$>$ There was a statistically significant positive linear correlation between the CD4 count and cardiac abnormalities. i.e decrease in CD4 count had a corresponding increasing cardiac abnormalities.

Chart 8: Prevalence of cardiac abnormalities in the study population

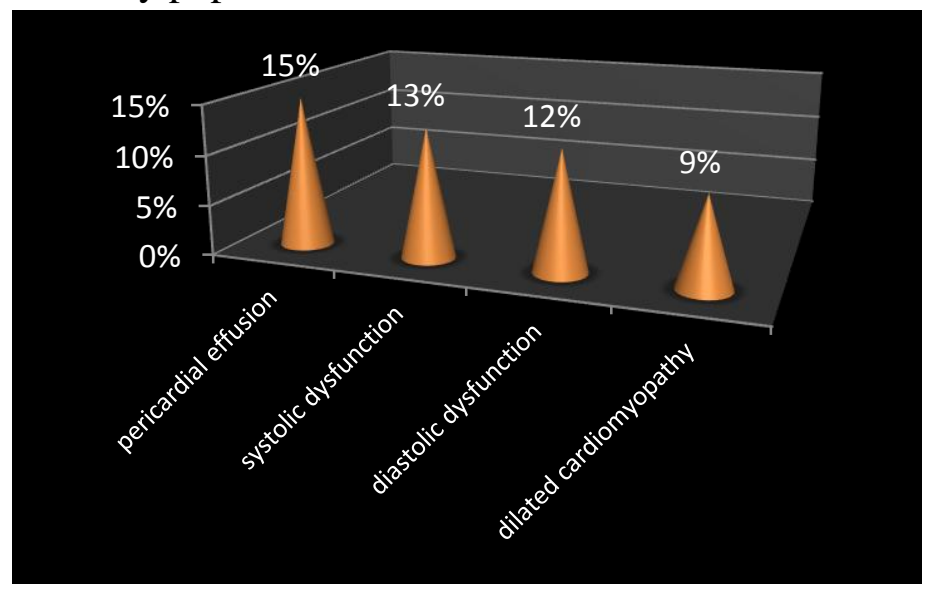

Comments: Pericardial effusion was the most common abnormality seen in the study population and all the abnormalities had statistically significant $\mathrm{p}$ value $<0.001$

\section{Discussion}

Cardiovascular abnormalities are more common in HIV infection in late stages of disease .This study was conducted in $200 \mathrm{HIV}$ patients including 
newly diagnosed and patients on ART attending ART clinic, Government Rajaji Hospital, Madurai. The study population were divided into 4 groups according to CD4 count.About $54 \%$ of study population were in the age group of 21-40 years and $42 \%$ of study populalation were in the age group of 41-60 years.

Around $70 \%$ of study population were on ART and $30 \%$ of the study population were newly diagnosed. Gender distribution were also almost equal in the study group.ECG and Echocardiography were performed in the study population.

In this study most of the patients with HIV infection had echocardiac abnormalities which were clinically quiescent. This suggests that echocardiographic screening is important tool for diagnosing subclinical cardiac abnormalities.

Pericardial effusion was the most commonly observed finding in HIV patients.It was seen in around $15 \%$ of cases and among that most of the cases were in stage $3 \& 4(\mathrm{CD} 4$ count $<200)$ with the spectrum ranging from asymptomatic mild effusion to massive pericardial effusion.

Pericardial effusion is the most common cardiac problem associated with shortened survival. Causes of pericardial effusion in HIV infection include tuberculosis, secondary infections, malignancy and part of generalised effusive process. Echocardiography is the diagnostic procedure and pericardiocentesis is needed in symptomatic patients.

Systolic dysfunction was present in $13 \%$ of patients with the $\mathrm{p}$ value $<0.001$. Most of patients were aymptomatic and had mild LV systolic dysfunction and were in stage 3\&4.Only few patients were asymptomatic. Systolic dysfunction is an important cause of morbidity and mortality and symptomatic heart failure occur in 6\% patients with advanced illness. Causes include myocarditis, dilated cardiomyopathy and coronary artery disease.

Diastolic dysfunction was also most commonly observed finding in this study. It was seen in $12 \%$ of patients with $\mathrm{p}$ value $<0.001$ and majority of the patients had were in stage $3 \& 4$ and most of the patients had exertional dyspnea. Diastolic dysfunction is due to ventricular filling abnormalities due to noncompliance of the ventricle.

Dilated cardiomyopathy (DCM) was found in 9\% of the patients in the study group with the $p$ value $<0.001$ and most of the cases were in stage $3 \& 4$.

Most common causes of DCM in HIV infection include myocarditis, opportunistic infections, nutritional and drug induced especially zidovudine.

Other cardiac abnormalities seen in the study group were regional wall motion abnormality (RWMA), infective endocarditis (IE) and pulmonary hypertension (PHT) which were statistically not significant. From this study we conclude that all cardiac abnormalities occur in late stage of HIV patients with low CD4 count .As the CD 4 count decreases cardiovascular abnormalities increases. So echocardiographic screening is mandatory in HIV patients with CD4 count $<500 /$ micrlitre.

Even though decrease in CD4 count well correlates with the cardiac abnormalities, this study had some limitations. Because there may be some confounding factors like smoking, alcohol and substance abuse, diabetes mellitus, hypertension and dyslipidemia which can also cause these cardiac manifestations.

Although the exact mechanism of the pathogenesis of cardiovascular abnormalities in HIV is multifactorial and poorly understood, progression of cardiac problems in HIV infection can be reduced by effective antiretroviral therapy

\section{Summary}

HIV infection is most oftenly associated with cardiac abnormalities. This study was conducted in $200 \mathrm{HIV}$ patients including newly diagnosed and patients on ART and the study population were divided into 4 groups according to CD4 count.About $54 \%$ of study population were in the age group of $21-40$ years and $42 \%$ of study populalation were in the age group of 41-60 years. 
Around $70 \%$ of study population were on ART and $30 \%$ of study population were newly diagnosed. Gender distribution were also almost equal in the study group.ECG and Echocardiography were performed in the study population.

Systolic dysfunction (13\%) and diastolic dysfunction(12\%) pericardial effusion(PE) (15\%) and dilated cardiomyopathy (DCM) $(9 \%)$ were most prevalent in the study group and the $\mathrm{p}$ value was $<0.001$, statistically significant and were seen most commonly in HIV patients receiving antiretroviral therapy

Other abnormalities like infective endocarditis (IE), regional wall motion abmormality (RWMA) and pulmonary hypertension(PHT) were seen in only few patients which were statistically not significant.

These cardiac abnormalities were more prevalent in stage 3 and 4 with CD4 count $<200 /$ microlitre. There is a positive linear correlation between prevalence of Systolic and diastolic dysfunction, pericardial effusion (PE) and dilated cardiomyopathy (DCM) with a fall in the CD4 count

\section{Conclusion}

Cardiovascular abnormalities are more common and predictable complications in late stages of HIV infection. This study was done.

* To highlight the various cardiovascular abnormalities occurring in HIV infection.

* Many of these abnormalities are associated with increased morbidity and mortality.

* Pericardial effusion, systolic and diastoloic dysfunction, and dilated cardiomyopathy are the most common cardiac abnormalities occurring in significant number of HIV patients with low CD4 count. So these parameters can also be used as predictors of disease progression.

* So all HIV patients with low CD4 count (<200/microlitre) should be screened for cardiac abnormalities. Early diagnosis and management of these complications is associated with increased survival rates and clinical outcomes in HIV patients.

\section{Bibliography}

1. S. Kaul, M. C. Fishbein and R. J. SIEGEL, "Cardiac Manifestations of Acquired Immune Deficiency Syndrome," American Heart Journal, Vol. 122, No. 2, 1991, pp. 535- 544. DOI: 10.1016/00028703(91)91013-D

2. S. Corallo, M. R. Mutinelli, M. Moroni, et al., "Echocar- diography Detects Myocardial Damage in AIDS," Euro- pean Heart Journal, Vol. 9, No. 8, 1998, pp. 887-892.

3. P. Aggarwal, A. Sharma, R. Bhardwaj and R. Rainam, "Myocardial Dysfunction in Human Immunodeficiency virus Infection: An Echocardiographic Study," Journal of the Association of Physicians of India, Vol. 57, 2009, pp. 745-746.

4. B. Anita, et al., "Cardiac Dysfunction Associated with HIV Infection," Journal of the Association of Physicians of India, Vol. 51, 2003, p. 1182.

5. R. Moreno, J. P. Villacastin, H. Bueno, et al., "Clinical and Echocardiographic Findings in HIV Patients with Pericardial Effusion," Cardiology, Vol. 88, No. 5, 1997, pp. 397-400. DOI: $10.1159 / 000177367$

6. A. M. Pellicelli, G. Barbaro, F. Palmieri, E. Girardi, C. D'Ambrosio, A. Rianda, G. Barbarini, D. Frigiotti, M. C. Borgia and N. Petrosillo, "Primary Pulmonary Hypertension in HIV Patients: A Systematic Review," Angiology, Vol. 52, No. 1, 2001, pp. 31-41.

7. D. Klein, L. B. Hurley, C. P. Quesenberry Jr. and S. Sid-ney, "Do Protease Inhibitors Increase the Risk for Coro-nary Heart Disease in Patients with HIV-1 Infection," Journal of Acquired Immune Deficiency Syndromes, Vol. 30, No. 5, 2002, pp. 471477. 
8. S. Castro, G. Migliau, A. Silvestri, et al., "Heart Involvement in AIDS: A Prospective Study during Various Stages of Diseases," European Heart Journal, Vol. 13, 1992, pp. 1452-1459.

9. R. B. Himelman, W. S. Chung, D. N. Chernoff, N. B. Schiller and H. Hollander, "Cardiac Manifestations of Human Immunodeficiency Virus Infection: A Two-Di- mensional Echocardiographic Study," Journal of the American College of Cardiology, Vol. 13, No. 5, 1989,

10. Chariot P, Perchet H, Monnet I. Dilated cardiomyopathy in HIV patients N Engl J Med 1999;340:732-5.

11. Barabaro G, LorenzoG, Grisorio B, et al. Incidence of dilated cardiomyopathy and detection of HIV in myocardial cells of HIV positive patients. N Engl J Med 1998;339:1093-9

12. Barbaro G. Cardiovascular manifestations of HIV infection. J R Soc Med 2001;94:384-90.827-38. 